\title{
A rare cause of hemoperitoneum: A case report of ruptured ileocolic artery aneurysm
}

\author{
Adem Bayraktar, M.D., Kaan Gök, M.D., Fatih Yanar, M.D., \\ Bahar Canbay Torun, M.D. Cemalettin Ertekin, M.D.
}

Department of General Surgery, İstanbul Universty İstanbul Faculty of Medicine, İstanbul-Turkey

\begin{abstract}
Visceral artery aneurysm (VAA) is very rare among vascular pathologies. Incidence reported in autopsy series and angiographic studies varies between $0.1 \%$ and $0.2 \%$. Most cases are asymptomatic and are diagnosed as result of complications, or incidentally, when imaging is performed for another reason. Three percent of VAAs are superior mesenteric artery (SMA) terminal branch aneurysms. Intra- and/ or extraperitoneal bleeding due to ruptured aneurysm is life-threatening condition and requires emergent intervention. Therefore, surgical or endovascular interventional treatment must be performed rapidly after diagnosis. Presently described is case of ileocolic artery aneurysm in a patient admitted with abdominal pain, nausea, and vomiting. Endovascular intervention had been planned; however, during hospitalization, aneurysm ruptured and emergent surgery was performed. Review of the literature is also presented.
\end{abstract}

Keywords: Acute abdomen; aneurysmal rupture; vascular aneurysm.

\section{INTRODUCTION}

Visceral artery aneurysm (VAA) is very rare among vascular pathologies. VAA was first described by Beaussiers in 1770, a splenic artery aneurysm found at autopsy. In I87I, Quincke described the symptoms of hepatic artery aneurysm. Kehr performed the first successful surgical procedure to treat VAA in 1903, and in 1932, Lindboe was the first to diagnose splenic aneurysm preoperatively with abdominal X-ray. Most cases are asymptomatic and are diagnosed as result of complications, or incidentally, when imaging is performed for another reason. Reported incidence has increased in recent years due to frequent use of imaging methods. ${ }^{[1]}$ In autopsy series, incidence varies between $0.1 \%$ and $0.2 \%{ }^{[2]}$ Three percent of VAAs are superior mesenteric artery (SMA) terminal branch aneurysms. Aneurysm is most commonly seen in the jejunal artery, followed by the middle colic artery, and

Address for correspondence: Adem Bayraktar, M.D. İstanbul Üniversitesi İstanbul Tıp Fakültesi, Genel Cerrahi Anabilim Dalı, İstanbul, Turkey

Tel: +90 212 - 631 1366 E-mail: dradem6I@gmail.com

Submitted: 03.02 .2016

Ulus Travma Acil Cerrahi Derg

2017;23(4):35I-353

doi: $10.5505 /$ tjtes. 2016.08095

Copyright 2017

TJTES the ileal artery. ${ }^{[3,4]}$ Most common causes are atherosclerosis, angiodysplasia, arteritis, and infection. ${ }^{[3,5]}$ Intra- and/or extraperitoneal bleeding as result of ruptured aneurysm is lifethreatening condition and requires emergent intervention. Therefore, surgical or endovascular interventional treatment must be performed rapidly after diagnosis.

In this article, we report a case of ileocolic artery aneurysm in a patient who was admitted with abdominal pain, nausea, vomiting. Endovascular intervention had been planned; however, during hospitalization, the aneurysm ruptured and emergent surgery was performed. We also present a review of the literature.

\section{CASE REPORT}

A 27-year-old male patient was admitted to emergency surgery department with abdominal pain. Physical examination revealed tenderness in the right lower quadrant of abdomen. Vital signs were stable. Abdominal ultrasonography (USG) demonstrated aneurysmal vascular lesion $57 \times 52 \mathrm{~mm}$ in size in the right lower quadrant, which was thought to originate from mesenteric vessels, and inside the aneurysmal sac there was a hyperechoic lesion with fluid level that could indicate thrombus. Abdominal and thoracic computerized tomography (CT) and $\mathrm{CT}$ angiography were performed. Aneurysmal dilatation distal to ileocolic artery approximately $5 \mathrm{~cm}$ in diameter was found. There was no additional vascular aneurysm or vascular 
pathology observed in thoracic or abdominal images or cardiovascular system images (Figs. I, 2). Hemoglobin level was $10.2 \mathrm{~g} / \mathrm{dL}$, hematocrit value was $31.3 \%$, and other coagulation parameters were normal. The patient did not have any signs of acute abdomen. Endovascular treatment was planned.

While hospitalized awaiting endovascular intervention, patient had sudden onset of abdominal distension, hypotension, and tachycardia. Emergent abdominal USG was performed, and extensive intraabdominal fluid was observed. The patient underwent emergent surgery with diagnosis of ruptured aneurysm. In exploratory laparotomy, large quantity of fresh blood in the abdomen, giant hematoma in the small bowel mesentery, and ruptured aneurysm in the terminal branches of ileocolic artery were detected (Fig. 3).

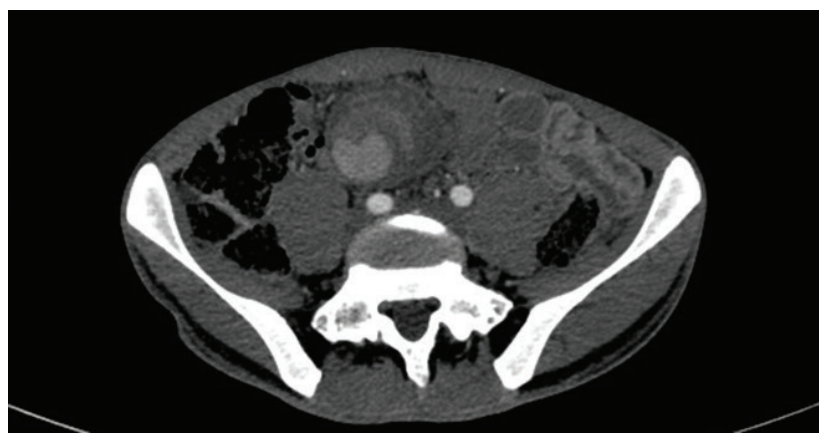

Figure 1. Axial computed tomography angiography image of aneurysmal dilatation approximately $5 \mathrm{~cm}$ in diameter located distal to ileocolic artery.

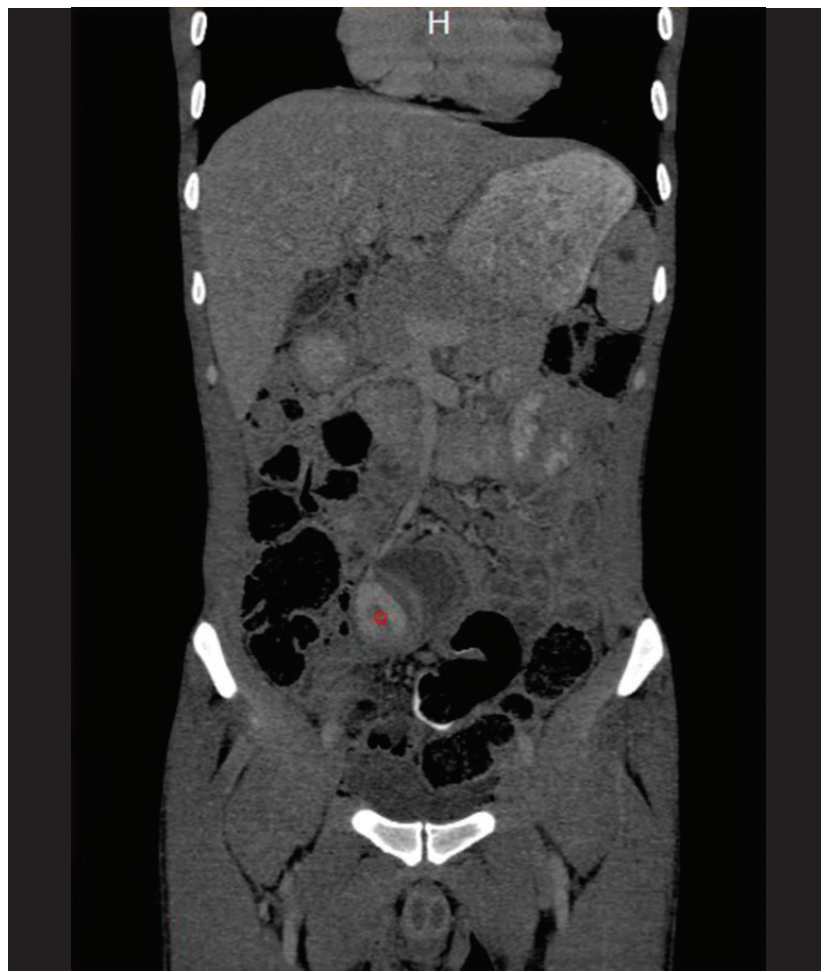

Figure 2. Coronal computed tomography angiography image of aneurysmal dilatation approximately $5 \mathrm{~cm}$ in diameter located distal to ileocolic artery.

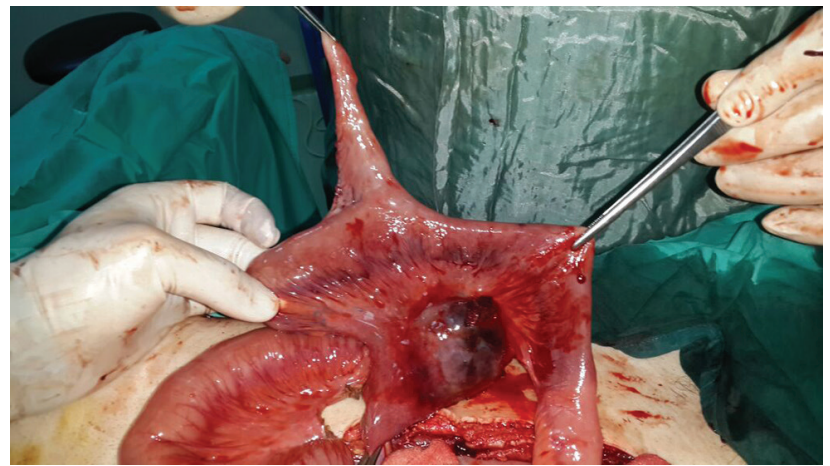

Figure 3. View of ileocolic arterial aneurysm rupture.

Preoperative blood pressure was $70 / 50 \mathrm{mmHg}$, pulse was $120 / \mathrm{bpm}$, hemoglobin was $5.1 \mathrm{~g} / \mathrm{dL}$, hematocrit was $15.3 \%$, $\mathrm{pH}$ was 7.05, lactate concentration was $6.3 \mathrm{mmol} / \mathrm{L}$, and base deficit was determined to be $-21.3 \mathrm{mmol} / \mathrm{L}$. Partial small bowel resection, including ruptured aneurysmal area, was performed. Anastomoses were avoided, due to hemodynamic and metabolic instability; loops of small intestine were exteriorized as end ileostomy. Three units of erythrocyte suspension were transfused peroperatively. Postoperatively, the patient was kept under observation in the intensive care unit, and transferred to service the next day. He was discharged from the hospital on postoperative $10^{\text {th }}$ day.

Microscopic examination of pathology specimen revealed recanalized thrombotic vascular structures in the mesenteric fatty tissue near the ruptured aneurysm. There were no signs indicating vasculitis. Stoma closure was performed second month postoperatively. At follow-up 6 months after surgery, the patient had no complications.

\section{DISCUSSION}

VAA is very rare among vascular pathologies, but reported incidence has increased in recent years due to frequent use of imaging methods. ${ }^{\left[{ }^{[}\right]}$In autopsy series and angiographic studies it has been said to be $0.1 \%$ to $0.2 \% .{ }^{[2]}$ Among cases of VAA, $3 \%$ are SMA terminal branch aneurysm. Aneurysm is most commonly seen in the jejunal artery, followed by middle colic artery and ileal artery. ${ }^{[3,4]}$ Most common causes are atherosclerosis, angiodysplasia, arteritis, and infection. ${ }^{[3,5]}$

Grotemeyer et al. reported in their study that $39.1 \%$ of VAAs are diagnosed incidentally, $60.9 \%$ of VAAs are symptomatic (abdominal pain, nausea, vomiting, jaundice, etc.), and $17.4 \%$ of VAAs cause hemorrhagic shock. ${ }^{[6]}$ Due to very high mortality and morbidity associated with VAA, treatment of incidental cases is recommended even when asymptomatic. ${ }^{[7]}$

It has been reported in the literature that $22 \%$ of VAAs are diagnosed after rupture. ${ }^{\left[{ }^{[]}\right.}$Risk of rupture is higher in pregnant women, patients who have many aneurysms, if aneurysm has diameter of more than $2 \mathrm{~cm}$, and in symptomatic patients. ${ }^{[9-11]}$ VAA is treated with surgery or endovascular intervention. 
Due to high probability of SMA terminal branch aneurysm rupture and end-organ damage, surgical treatment is usually preferred in these cases. Ligation of aneurysm and bowel resection procedure defined by Cooley and De Bakey in 1953 is still treatment of choice in surgery today. ${ }^{[12]}$ Endovascular treatment can be attempted in patients who had previous abdominal surgery or in patients with multiple comorbidities. ${ }^{[13]}$ This treatment can be used in ruptured aneurysm ${ }^{[13]}$ and in small asymptomatic aneurysm. Aneurysm embolization (coil, glue, etc.) or covered stenting can be performed endovascularly. However, if there is suspicion of mycotic infection as etiology, high risk of infection of graft material should be considered. ${ }^{[10,14]}$ Endovascular treatment can be performed in these cases with low rate of mortality and morbidity; however, many aneurysms may not be suitable for this treatment. Furthermore, experienced staff and angiography units with proper technical infrastructure are needed for endovascular treatment, and such facilities are available in only limited number of hospitals. Mortality rate due to ruptured aneurysm ranges from $8.5 \%$ to $75 \% .{ }^{[8]}$ Our patient was diagnosed with abdominal pain, and endovascular intervention was planned, but emergent surgery became necessary due to rupture of aneurysm. We believe that the fact that the rupture occurred in hospital conditions prevented mortality in this instance. Anastomosis was avoided because the patient was in hemorrhagic shock. Small bowel loops had severe edema due to resuscitation with intravenous fluid in a short time. This case illustrates that terminal branch aneurysm of SMA can rupture at any time. Therefore, performing treatment as soon as it is diagnosed may reduce mortality and morbidity.

VAA is rare among vascular pathologies. Most cases are asymptomatic. VAA is often detected only once complications or symptoms arise, or incidentally, when imaging is performed for another reason. Once SMA terminal branch aneurysm is diagnosed, treatment is recommended as soon as possible due to high mortality and morbidity of complications. Even though endovascular treatment can be performed in selected cases, surgical treatment is preferred due to possibility of rupture and end-organ damage.
Conflict of interest: None declared.

\section{REFERENCES}

1. Sachdev-Ost U. Visceral artery aneurysms: review of current management options. Mt Sinai J Med 2010;77:296-303. [CrossRef]

2. Tulsyan N, Kashyap VS, Greenberg RK, Sarac TP, Clair DG, Pierce G, et al. The endovascular management of visceral artery aneurysms and pseudoaneurysms. J Vasc Surg 2007;45:276-83. [CrossRef]

3. Silva MB, Choi L, Cheng CC. Peripheral arterial occlusive disease. In: Townsend C, Beauchamp D, Evers M, Mattox K, editors. Sabistan. Textbook of Surgery. 19th ed. Philadelphia: WB Saunders; 2012. pp. 1725-84.

4. Maisonnette F, Thognon P, Durand-Fontanier S, Valleix D, Lachachi F, Descottes B. Rupture of mesenteric artery branch aneurysm. Ann Vasc Surg 2001;15:684-6. [CrossRef]

5. Kurdal AT, Cerrahoglu M, Iskesen I, Sirin H. Superior mesenteric artery branch--jejunal artery aneurysm. Interact Cardiovasc Thorac Surg 2010;11:859-61. [CrossRef]

6. Grotemeyer D, Duran M, Park EJ, Hoffmann N, Blondin D, Iskandar F, et al. Visceral artery aneurysms--follow-up of 23 patients with 31 aneurysms after surgical or interventional therapy. Langenbecks Arch Surg 2009;394:1093-100. [CrossRef]

7. Horton KM, Smith C, Fishman EK. MDCT and 3D CT angiography of splanchnic artery aneurysms. AJR Am J Roentgenol 2007;189:641-7.

8. Chiesa R, Astore D, Guzzo G, Frigerio S, Tshomba Y, Castellano R, et al. Visceral artery aneurysms. Ann Vasc Surg 2005;19:42-8. [CrossRef]

9. Wagner WH, Allins AD, Treiman RL, Cohen JL, Foran RF, Levin PM, et al. Ruptured visceral artery aneurysms. Ann Vasc Surg 1997;11:3427. [CrossRef]

10. Sachdev U, Baril DT, Ellozy SH, Lookstein RA, Silverberg D, Jacobs TS, et al. Management of aneurysms involving branches of the celiac and superior mesenteric arteries: a comparison of surgical and endovascular therapy. J Vasc Surg 2006;44:718-24. [CrossRef]

11. Carmeci C, McClenathan J. Visceral artery aneurysms as seen in a community hospital. Am J Surg 2000;179:486-9. [CrossRef]

12. De Bakey ME, Cooley DA. Successful resection of mycotic aneurysm of superior mesenteric artery; case report and review of literature. Am Surg 1953;19:202-12.

13. Mendonça CT, Weingartner J, de Carvalho CA, Costa DS. Endovascular treatment of contained rupture of a superior mesenteric artery aneurysm resulting from neurofibromatosis type I. J Vasc Surg 2010;51:461-4.

14. Gabelmann A, Görich J, Merkle EM. Endovascular treatment of visceral artery aneurysms. J Endovasc Ther 2002;9:38-47. [CrossRef]

\section{OLGU SUNUMU - ÖZET}

\section{Nadir görülen bir hemoperitonium nedeni: İleokolik arter anevrizma rüptürü olgu sunumu Dr. Adem Bayraktar, Dr. Kaan Gök, Dr. Fatih Yanar, Dr. Bahar Canbay Torun, Dr. Cemalettin Ertekin \\ İstanbul Üniversitesi İstanbul Tıp Fakültesi, Genel Cerrahi Anabilim Dalı, İstanbul}

Visseral arter anevrizmaları (VAA) vasküler patolojiler arasında çok nadir görülmektedir. Otopsi çalışmalarında görülme sıklığı \%0. I-\%0.2 arasında değişmektedir. Çoğu olguda semptomsuzdurlar ve komplikasyonları sonucu tanı alırlar ya da başka nedenle yapılan görüntülemeler sırasında insidental olarak saptanırlar. Visseral arter anevrizmaları arasında süperiyor mezenterik arter (SMA) uç dal anevrizmaları \%3 oranında görülmektedir. Anevrizma rüptürü sonucu intra ve/veya ekstraperitoneal kanamalar hayatı tehdit etmekte ve acil müdahale gerektirmektedir. Bu nedenle tanı konulduktan sonra hızlı bir şeklide cerrahi ya da endovasküler girişim ile tedavi edilmeleri gerekmektedir. Bu yazıda, karın ağrısı, bulantı, kusma nedeni ile başvuran ve görüntülemelerinde ileokolik arterde anevrizma saptanıp endovasküler girişim planlandığı ve hastanede yatış sırasında rüptüre olan, acil cerrahi girişim uygulanan olguyu sunmayı ve literatür taraması yapmayı amaçladık.

Anahtar sözcükler: Akut karın; anevrizma rüptürü; vasküler anevrizma.

Ulus Travma Acil Cerrahi Derg 2017;23(4):35I-353 doi: 10.5505/tjtes.2016.08095 